J.-B.T. and Y.B. act as proctors for Medtronic Inc.

Z.J. received consulting fees from Medtronic Inc.

O.V. has nothing to disclose with regard to commercial support.

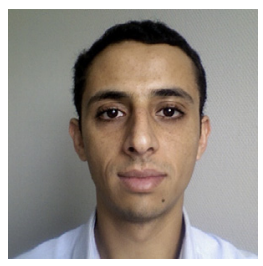

\section{WHAT MATTERS MORE IN TESTING BACTERIAL ADHESION: FLOW CONDITIONS OR CHOICE OF BACTERIAL STRAIN?}

To the Editor:

We read with great interest the work published by Veloso and colleagues ${ }^{1}$ that investigated the bacterial adherence to pulmonary valve graft tissues under static and flow conditions. These experiments were achieved using wild bacterial strains of Staphylococcus aureus, Staphylococcus epidermidis, and Streptococcus sanguinis and the following valvular substrates: bovine pericardium patch, bovine jugular vein, and cryopreserved homograft. The authors concluded that the surface composition of bovine jugular vein and homograft tissues themselves, bacterial surface proteins, and shear forces per se were not the prime determinants of bacterial adherence. These results are in contradiction with our findings. We demonstrated that the bacterial adherence was greater with bovine jugular vein compared with other substrates and concluded that the Melody valve (Medtronic, Inc, Minneapolis, Minn) represented the preferential substrate for differential bacterial adhesions. ${ }^{2}$ Even if these results might appear contradictory at first sight, they might just reflect a difference in experimental setting. Veloso and colleagues ${ }^{1}$ tested wild bacterial strains when we used pathogenic strains isolated from patients diagnosed with Melody valve infective endocarditis. Various studies have shown that bacterial adhesion is influenced by the pathogenicity of the bacteria. Some strains might be more aggressive than others. These pathogenic strains are known to develop pathogenic surface molecules that allow these isolates to preferentially bind and infect several medical devices. Adhesion is a complex mechanism involving platelets or bacterial binding proteins and in which coagulation and inflammation processes are not fully understood. Being

\footnotetext{
The Editor welcomes submissions for possible publication in the Letters to the Editor section that consist of commentary on an article published in the Journal or other relevant issues. Authors should: • Include no more than 500 words of text, three authors, and five references. • Type with double-spacing. • See http://jtcs.ctsnetjournals.org/ misc/ifora.shtml for detailed submission instructions. • Submit the letter electronically via jtcvs.editorialmanager.com. Letters commenting on an article published in the JTCVS will be considered if they are received within 6 weeks of the time the article was published. Authors of the article being commented on will be given an opportunity of offer a timely response ( 2 weeks) to the letter. Authors of letters will be notified that the letter has been received. Unpublished letters cannot be returned.
}

able to build more sophisticated in vitro studies mimicking what happening in vivo would provide evidence to understand why we and others have shown a higher incidence of endocarditis with bovine jugular vein valves (ie, Contegra [Medtronic] or Melody) than other types of right ventricle-to-pulmonary artery conduits. ${ }^{3,4}$ Ultimately, those studies may help to develop conservative treatments for valvular implants targeting specifically tissular binding proteins and to test the effects of antiplatelet therapy on bacterial adhesion. ${ }^{5}$

Zakaria Jalal, $M D^{a, b, c}$

Olivier Villemain, $M D, P h D^{d}$

Jean-Benoit Thambo, $M D, P h D^{a, b, c}$

Younes Boudjemline, $\mathrm{MD}, P h \mathrm{D}^{e}$

${ }^{a}$ Department of Paediatric and Adult Congenital Cardiology

Bordeaux University Hospital Pessac, France

${ }^{b}$ Institut Hospitalo Universitaire Liryc Electrophysiology and Heart Modeling Institute fondation Bordeaux Université Bordeaux, France

${ }^{c}$ Institut national de la santé et de la recherche médicale Centre de recherche Cardio-Thoracique de Bordeaux

Bordeaux, France

${ }^{d}$ Necker Enfants malades Assistance publique des hopitaux de Paris Université Paris Descartes

Sorbonne Paris Cité Paris, France

${ }^{e}$ Cardiac Catheterization Laboratories Sidra Heart Center Sidra Medicine Doha, Qatar

This study received financial support from the French Government as part of the "Investments of the Future" program managed by the National Research Agency (ANR), Grant reference ANR10-IAHU-04.

\section{References}

1. Veloso TR, Claes J, Van Kerckhoven S, Ditkowski B, Hurtado-Aguilar LG, Jockenhoevel S, et al. Bacterial adherence to graft tissues in static and flow conditions. J Thorac Cardiovasc Surg. 2018;155:325-32.e4.

2. Jalal Z, Galmiche L, Lebeaux D, Villemain O, Brugada G, Patel M, et al. Selective propensity of bovine jugular vein material to bacterial adhesions: an in-vitro study Int J Cardiol. 2015;198:201-5.

3. Sharma A, Cote AT, Hosking MCK, Harris KC. A systematic review of infective endocarditis in patients with bovine jugular vein valves compared with other valve types. JACC Cardiovasc Interv. 2017;10:1449-58.

4. Van Dijck I, Budts W, Cools B, Eyskens B, Boshoff DE, Heying R, et al. Infective endocarditis of a transcatheter pulmonary valve in comparison with surgical implants. Heart. 2015;101:788-93.

5. Brennan MP, Loughman A, Devocelle M, Arasu S, Chubb AJ, Foster TJ, et al Elucidating the role of Staphylococcus epidermidis serine-aspartate repeat protein G in platelet activation. J Thromb Haemost. 2009;7:1364-72.

https://doi.org/10.1016/j.jtcvs.2018.03.085 